\title{
Planning and Funding of Higher Education in Nigeria: The Challenges
}

\author{
Samuel Akinyemi ${ }^{1} \&$ Ofem Igot Bassey ${ }^{2}$ \\ ${ }^{1}$ Faculty of Education, Lagos State University, Lagos, Nigeria \\ ${ }^{2}$ Department of Educational Management, Lagos State University, Lagos, Nigeria \\ Correspondence: Samuel Akinyemi, PhD, AIMM. Faculty of Education, Lagos State University, Lagos, Nigeria. \\ Tel: 234-808-388-5784. E-mail: akinyemisam2006@yahoo.com
}

Received: April 12, 2012 Accepted: April 24, 2012 Online Published: June 25, 2012

doi:10.5539/ies.v5n4p86 URL: http://dx.doi.org/10.5539/ies.v5n4p86

\begin{abstract}
Higher education remains the pivot of national development in Nigeria. This is because the stock of highly-educated individuals produced by higher education institutions plays an important role in the innovation and the sustainable development of any society. However, over time, these institutions have experienced increase in enrolments and yet the number of candidates seeking admission into these institutions outpaces the available spaces in the institutions. Inadequate fiscal resources have also eroded the desired qualitative higher education and the needed national development. In this paper, challenges facing planning and funding of qualitative higher education in Nigeria are examined. The paper therefore infers the need for proper planning of higher education system to ensure qualitative higher education so as to reduce educational wastages and enhance effective utilization of the available educational scarce resources.
\end{abstract}

Keywords: planning, funding, higher education, challenges, Nigeria

\section{Introduction}

The role of higher education as essential to national development cannot be over emphasized. This is due to the contribution of higher education in producing higher-level skills and competencies as essential to national development particularly in the context of globalization and the shift towards knowledge economies. For these reasons, countries all over the world, Nigeria inclusive are giving higher education the needed policy attention.

Higher education includes all types of study, training or trainings for research at post-secondary level, provided by the universities or other educational establishments that are approved as institutions of higher education by competent state authorities (UNESCO, 2003).

Also Johnstone (2006) opines that higher education as an agent of change, national growth and instrument for the realization of collective aspiration should contribute to the development of the entire education system through teacher education, curriculum development and educational research thereby providing the crucial mass skills and educated populace needed by any country to ensure genuine endogenous sustainable development.

Meanwhile in the Nigerian Education system, Higher education is the education given after secondary education. It constitutes Federal universities, State Universities, University of technology, University of Agriculture, polytechnics and Colleges of education. They are often referred to as either Post Secondary Education, Tertiary Institutions, or Institutions of Higher learning owned either by the Federal Government, State Government or Private Agencies as provided by the National Policy on Education.(NPE,2004)

Globally, UNESCO (2006), on world enrollment of the number of tertiary students per 100,000 inhabitants in the world bank countries confirms that over six fold increase in students' enrollment worldwide rose from 13 million in 1996 to 102 million in 2003. UNESCO (2006) also reports that a widening gap has been observed between industrially developed, developing countries; particularly the least developed countries with regards to access and resources for higher learning and research leading to increase socio-economic stratification and greater difference in education opportunity within countries.

According to the Global Education digest (2009), the number of students pursuing tertiary education has skyrocketed over the past 37 years, growing five-fold from 28.6 million in 1970 to 152.5 million in 2007. This translates into an average annual increase of 4.6. The Sub-Saharan Africa has experienced the highest average regional growth rate with student enrolments that have risen by an average of 8.6 percent each year. Yet, in spite 
of this achievement, the region still lags behind other regions in terms of total tertiary student enrolments. Today, there are 20 times more students than in 1970, with an additional 3.9 million enrolment (GED, 2009). In the same vein, UNESCO (2003) reports that many countries with higher education system have higher expansion rates and increase in students enrolment than anticipated.

Sommers (2006) in his study of higher education funding and enrollment observes that there are three kinds of demand for higher education which include:

1) Students seeking access to higher education;

2) Employers seeking to hire appropriately skilled graduates since the labour market depends on the products of higher education who when employed, help create wealth which enhances the individual and national development.

3) Regions seeking the presence of higher education that will catalyze development.

Context-globalization has also influenced the demand for higher education by making both employers and students to demand acquisition of higher skills. This is because higher education is believed to offer the individual with new opportunities relating to technologies that help improve the ways in which knowledge can be produced, managed, disseminated, accessed and controlled.

Besides, Higher education helps integrate learners into the global knowledge society where the educated workers are able to perceive technological change clearly and adapt to it more effectively through improved knowledge and skills. Globalization is said to allow for knowledge sharing, international co-operation, new opportunities that will help reduce the gap between separating the developing from the least developed countries from the industrially developed countries. Hence, international cooperation and exchange are the major avenues for advancing higher education worldwide.

On the African scene, John (2006) who is the world bank chief economist for developing countries and the African region confirms that Africa has made a near progress in social outcome although economic outcomes are still diverse; that sixteen (16) African countries have sustained their annual gross Domestic Product (GDP) growth rate in excess of $4.5 \%$ since the mid 1990's and that primary enrollment rate has significantly risen across the continent. For example gross primary enrollment rate shot up to $93 \%$ in 2004 from $72 \%$ in 1990 , thereby raising literacy rate from $50 \%$ to $65 \%$ in 2002 . Reports on increase in enrollment were not recorded in secondary and tertiary levels of education.

Banya (2001), on Sub-Saharan Africa, also confirms that increase in students enrollment is one of the major areas of crisis in higher education as the available limited resources (physical and human) have not been able to meet the enrolment needs thereby having implications for low quality education. Gobin (2006) attributes the tangible progress in Africa on delivering better health, education, growth, trade and poverty reduction outcome to the impact of education in Africa.

In Nigeria, NUC (2006) reports that the Nigerian education system has expanded from one University in 1948 (University of Ibadan- University College London) to eighty (80) in 2005 of which include 27 Federal, 26 State, 24 private and four (4) Inter- universities.

The importance and contribution of higher education to the development of any society cannot be overemphasized as it is believed to be unique and vital helping to illuminate the individual's mind through the knowledge acquired who in turn contributes meaningfully to the society. Due to this attached importance to higher education, the universal declaration on human right states in article two (2) paragraph one (1) that "everyone has access to education and that higher education should be equally accessible to all on the basis of merit and individual capability and ensure that the values and ideals of a culture of peace prevail and is sustained; and suggests that the development of higher education should be considered, its quality and relevance enhanced."

Furthermore, Obanya (2004) reports that high enrolments in higher institutions also known as 'massification' has greater challenge in ensuring quality since the available resources have not matched this increase in the number of students. According to The Economist (2005), Chevailler (2000), and Adu and Orivel (2006), the overcrowding of lecture hall, laboratories, libraries amongst result in deterioration of physical facilities and wearing out of the equipment.

Nevertheless, tertiary education systems in the Sub-Saharan Africa, particularly Nigeria are under considerable strain as these higher growth rates have posed more challenges. To begin with, higher education in Nigeria is faced with the challenges of high demand for admission places leading to escalated enrolments, insufficient funds and physical facilities, inadequate qualified academic staff, and the unemployment of the higher education 
graduates all of which have led to high cost of education. There is therefore the need for proper planning of higher education system as this will help in reducing educational wastages, enhancing proper allocation of scarce resources and tackling the problem of unemployment of higher education graduates.

Planning is an important project management and time management techniques which involves the process of setting goals, developing strategies, and outlining tasks and schedules to accomplish the goals. According to Amokaye (2004), "Planning as a concept is a terminology that is very difficult to define but it has been agreed to involve a very complex management activity that requires integrating the physical and biological resources in compatible use, and coordinating social, cultural, economic, legal and political demands and constraints. Olayemi (2000) sees planning as the preparation and construction of plans in accordance with which growth and extension of a tow, is to be regulated so as to make the most of the natural advantages of the site, and to secure the most advantageous conditions of housing and traffic.

Educational planning therefore, is concerned with the problems of how to make the best use of limited resources allocated to education in view of the priorities given to different stages of education or different sectors of education and the need of the economy. Adeleye (2008) has identified three types of Planning Education (PE) in Nigeria to include: Educational Training, Professional Training and NITP/TOPREC Training

This paper therefore examines the challenges in planning and funding higher education in Nigeria with a view to suggesting ways by which these problems can curbed.

\section{Challenges}

\subsection{Low Enrolment/Low Participation Rates}

The Nigerian higher education is faced with the global challenge of institutional expansion, high demand for admission places and low enrollments. According to National Universities Commission (2010), the Nigerian university education system has expanded from one University College in 1948 to 113 in 2010 which consist of 36 Federal, 35 State and 41 private universities. In spite of this upsurge in the number of universities, there has been a wide gap between demand for admission and supply of admission. This is reflected in the Table 1 below.

Table 1. Total application and enrolments in all Nigerian universities (2003/2004- 2007/2008)

\begin{tabular}{|c|c|c|c|c|c|c|c|}
\hline Year & $\begin{array}{l}\text { Application } \\
\text { Into Nigerian } \\
\text { Universities } \\
\text { (1) } \\
\end{array}$ & $\begin{array}{c}\text { Federal } \\
\text { Universities } \\
\text { A } \\
\end{array}$ & $\begin{array}{c}\text { State } \\
\text { Universities } \\
\text { B } \\
\end{array}$ & $\begin{array}{c}\text { Private } \\
\text { Universities } \\
\text { C } \\
\end{array}$ & $\begin{array}{c}\text { Total } \\
\text { A+B+C } \\
\\
(2) \\
\end{array}$ & $\begin{array}{l}\text { Diff. } \\
\text { (1)-(2) }\end{array}$ & $\begin{array}{r}\% \% \\
\text { admitted }\end{array}$ \\
\hline 2003/04 & $1,046,940$ & 62,242 & 37,434 & 3,360 & 103,036 & 943,904 & 9.84 \\
\hline $2004 / 05$ & 838,051 & 55,505 & 47,236 & 3,214 & 105,955 & 732,096 & 12.64 \\
\hline 2005/06 & 917,960 & 33,931 & 30,452 & 2,370 & 66,753 & 851,207 & 7.27 \\
\hline 2006/07 & 912,350 & 33,803 & 34,275 & 4,110 & 72,188 & 840,162 & 7.91 \\
\hline 2007/08 & $1,054,078$ & 20,716 & 21,517 & 5,243 & 47,476 & $1,006,602$ & 4.50 \\
\hline
\end{tabular}

Source: Adapted from JAMB (2009) and National Bureau of Statistics (2009)

In Table 1, a total of 1,054,078 applications were made for admission into the Nigerian Universities in $2007 / 2008$ session. Out of this total, only 47,496 enrolments resulting in 4.50 percent were made. This shows a drop by 6.51 percent over the previous enrolment (2006/2007).By implication, less than 20 percent of those who sought access into Nigerian universities actually got admitted in the years under study. This problem is also applicable to other forms of the Nigerian tertiary institutions.

Table 2. Total enrolment in all Colleges of Education in Nigeria by year (2004-2008)

\begin{tabular}{lll}
\hline Year & Number Enrolled & \% Increase in Enrolment \\
\hline $2003 / 2004$ & 328156 & - \\
$2004 / 2005$ & 355560 & 5.35 \\
$2005 / 2006$ & 244569 & -30.62 \\
$2006 / 2007$ & 255926 & 4.17 \\
$2007 / 2008$ & 225362 & -11.94 \\
\hline
\end{tabular}

Source: National Statistics Bureau (2009) 
From Table 2, enrolment figures into the Nigerian colleges of education reveal a downward trend from 2005 with 2006 and 2008 having negative enrolments of -30.62 per cent and -11.94 per cent respectively. This downward trend could be attributed to: (i) individual preference for degree certificates from degree awarding institutions such as universities to the National certificate of education (NCE) awarded in colleges of education and (ii) the low social status accorded the teaching profession in Nigeria therefore, prospective students tend to opt for studying other disciplines at the university level of education.

Table 3. Total enrolment in all Monotechnics and Polytechnics in Nigeria by year (2001-2005)

\begin{tabular}{lllll}
\hline & \multicolumn{2}{c}{ Monotechnics } & \multicolumn{2}{c}{ Polytechnics } \\
Year & Number Enrolled & \% Increase in Enrolment & Number Enrolled & \% Increase in Enrolment \\
\hline $2000 / 2001$ & 15,003 & 0 & 180,395 & 0 \\
$2001 / 2002$ & 17,727 & 18.16 & 259,450 & 43.82 \\
$2002 / 2003$ & 18,779 & 5.88 & 285,345 & 9.98 \\
$2003 / 2004$ & 19,869 & 5.86 & 226,682 & $(-20.56)$ \\
$2004 / 2005$ & 20,853 & 4.95 & 311,844 & 37.57 \\
\hline
\end{tabular}

Source: National Statistics Bureau (2009)

\subsection{Staffing}

Staffing policy is another challenge facing higher education in Nigeria

Table 4. Number of Teachers in Federal Universities by Major Disciplines, 2001/2002 - 2005/2006

\begin{tabular}{lrrrrr}
\hline Discipline & $\mathbf{2 0 0 1 / 2 0 0 2}$ & $\mathbf{2 0 0 2} / \mathbf{2 0 0 3}$ & $\mathbf{2 0 0 3 / 2 0 0 4}$ & $\mathbf{2 0 0 4 / 2 0 0 5}$ & $\mathbf{2 0 0 5} / \mathbf{2 0 0 6}$ \\
\hline Administration & 1,141 & 890 & 1,181 & 982 & 773 \\
Agriculture & 1,757 & 1,979 & 2,317 & 1,533 & 1,428 \\
Arts & 1,417 & 1,719 & 1,434 & 1,598 & 1,660 \\
Education & 1,418 & 1,559 & 1,370 & 1,515 & 1,552 \\
Engine ering Technology & 1,966 & 1,907 & 2,171 & 1,992 & 1,886 \\
Environmental Science & 696 & 820 & 682 & 769 & 889 \\
Law & 424 & 350 & 433 & 523 & 538 \\
Medicine & 1,780 & 2,004 & 1,996 & 2,041 & 2,027 \\
Pharmacy & 253 & 410 & 290 & 400 & 376 \\
Science & 3,153 & 3,872 & 3,495 & 3,099 & 2,986 \\
Social Sc ience & 1,130 & 1,272 & 775 & 1,283 & 1,398 \\
Veterinary Medicine & 290 & 379 & 515 & 381 & 377 \\
\hline Total & $\mathbf{1 5 , 4 2 5}$ & $\mathbf{1 7 , 1 6 1}$ & $\mathbf{1 6 , 6 5 9}$ & $\mathbf{1 6 , 1 1 6}$ & $\mathbf{1 5 , 8 9 0}$ \\
\hline
\end{tabular}

Source: National Universities Commission

Table 4 reveals only marginal increase in the number of university teachers from 15,425 in 2001/2002 to 15,890 in $2005 / 2006$. This is ridiculous. There has been a downward trend in the number of university teachers from $2003 / 2004$ to $2005 / 2006$. This could in part be attributed to the departure of some university teachers to other countries in search of greener pastures due to poor condition of service and facilities (physical and financial) which are inadequate compared to the raising increase in enrolments in the Nigerian higher education institutions. 
Table 5. Student/Teacher Ratio in Federal Universities, (2001-2006)

\begin{tabular}{|c|c|c|c|c|c|c|}
\hline \multirow[t]{2}{*}{ DISCIPLINES } & \multicolumn{6}{|c|}{ YEAR } \\
\hline & $2001 / 2002$ & $2002 / 03$ & $2003 / 04$ & $2004 / 05$ & 2005.06 & NUC G uideline \\
\hline ADMINISTRATION & 1 & 33 & 38 & 49 & 38 & 30 \\
\hline AGRICULTURE & 11 & 14 & 13 & 17 & 15 & 15 \\
\hline ARTS & 22 & 18 & 25 & 24 & 20 & 30 \\
\hline EDUCATION & 24 & 22 & 35 & 32 & 31 & 30 \\
\hline $\begin{array}{l}\text { ENGR/TECHNOLOGY } \\
\text { EIN V IKUNIVIEINI AL }\end{array}$ & 24 & 27 & 24 & 30 & 30 & 30 \\
\hline SCIENCE & 16 & 18 & 12 & 25 & 20 & 30 \\
\hline LAW & 34 & 40 & 36 & 35 & 30 & 15 \\
\hline MEDICINE & 15 & 13 & 14 & 15 & 12 & 30 \\
\hline PHARMARCY & 23 & 14 & 21 & 14 & 12 & 15 \\
\hline SCIENCES & 19 & 19 & 23 & 32 & 25 & 15 \\
\hline SOCIAL SCIENCES & 40 & 30 & 70 & 41 & 40 & 20 \\
\hline VET MEDICINE & 12 & 9 & 14 & 10 & 10 & 30 \\
\hline TOTAL & 266 & 257 & 325 & 324 & 283 & 10 \\
\hline
\end{tabular}

Source: National Universities Commission. (2010).

NOTE:*NUC guideline implies Students/Teacher Ratio (as Standard)

The Student/Teacher ratio as shown in table 5 is high for all disciplines except for Agriculture, Arts, Medicine and veterinary Medicine when compared to the required standard by the National Universities Commission.

\subsection{Funding}

Funding is the life wire of any organization; however it is one of the challenges facing higher education in Nigeria.

Table 6. Summary of Education Trust Fund Allocations to Institutions, 2003 - 2007

\begin{tabular}{|c|c|c|c|c|c|c|c|c|c|c|}
\hline \multirow[b]{2}{*}{$\begin{array}{l}\text { A ge } \\
\text { Group }\end{array}$} & \multirow[b]{2}{*}{ Total } & \multicolumn{9}{|c|}{ Educational Aattainment } \\
\hline & & None & Nursery & Primary & $\begin{array}{l}\text { JSS/Mo dern } \\
\text { School }\end{array}$ & $\begin{array}{l}\text { SSS/SEC/ } \\
\text { T T C }\end{array}$ & $\underset{\mathrm{E}}{\mathrm{OND} / \mathrm{NC}}$ & $\begin{array}{c}\text { University } \\
\text { Grad uate/H } \\
\text { ND }\end{array}$ & $\begin{array}{l}\text { Post } \\
\text { Gadua te }\end{array}$ & Other \\
\hline 06 -Sep & $13,642,012$ & $5,251,369$ & $8,233,381$ & 157,262 & - & - & - & - & - & - \\
\hline Oct-14 & $16,115,528$ & $4,963,254$ & $5,986,104$ & $4,419,589$ & 744,888 & 1,693 & - & - & - & - \\
\hline $15-19$ & $14,899,419$ & $3,552,684$ & 597,395 & $3,342,376$ & $5,464,661$ & $1,699,725$ & 150,952 & 24,010 & 0 & 67,616 \\
\hline $20-24$ & $13,435,079$ & $3,562,625$ & 61,318 & 771,209 & $3,254,607$ & $4,505,014$ & 781,666 & 365,294 & 44,520 & 88,826 \\
\hline $25-29$ & $12,211,426$ & $3,641,219$ & 67,195 & 958,734 & 976,337 & $4,378,367$ & $1,163,827$ & 828,518 & 96,617 & 100,612 \\
\hline $30-34$ & $9,467,538$ & $3,278,838$ & 59,573 & 894,167 & 314,542 & $3,076,233$ & 847,667 & 770,453 & 132,154 & 93,911 \\
\hline $35-39$ & $7,331,755$ & $2,471,327$ & 47,521 & 745,631 & 259,572 & $2,305,282$ & 693,677 & 599,168 & 134,586 & 74,991 \\
\hline $40-44$ & $6,456,470$ & $2,625,025$ & 41,652 & 646,244 & 201,706 & $1,650,918$ & 561,979 & 515,477 & 136,763 & 76,706 \\
\hline $45-49$ & $4,591,293$ & $1,775,001$ & 32,390 & 538,637 & 156,533 & $1,111,634$ & 409,163 & 401,397 & 113,344 & 53,194 \\
\hline $50-54$ & $4,249,219$ & $2,090,642$ & 30,500 & 479,022 & 133,301 & 799,564 & 272,290 & 293,254 & 90,446 & 60,200 \\
\hline $55-59$ & $2,066,247$ & 936,933 & 15,813 & 263,685 & 81,192 & 410,974 & 133,119 & 148,163 & 48,055 & 28,313 \\
\hline $60-64$ & $2,450,286$ & $1,440,136$ & 19,721 & 256,699 & 87,757 & 323,662 & 111,482 & 130,215 & 43,534 & 37,080 \\
\hline $65-69$ & $1,151,048$ & 663,752 & 15,261 & 154,331 & 54,649 & 110,343 & 52,920 & 62,767 & 21,457 & 15,568 \\
\hline $70-74$ & $1,330,597$ & 884,783 & 14,814 & 146,770 & 49,072 & 97,401 & 43,940 & 52,923 & 18,709 & 22,185 \\
\hline $75-79$ & 579,838 & 371,666 & 7,245 & 68,416 & 25,314 & 47,840 & 19,440 & 23,304 & 8,375 & 8,238 \\
\hline $80-84$ & 760,053 & 532,798 & 9,193 & 74,594 & 25,092 & 51,880 & 21,173 & 24,605 & 8,184 & 12,534 \\
\hline $85+$ & 715,225 & 492,923 & 8,780 & 70,967 & 25,071 & 52,260 & 21,820 & 24,974 & 8,539 & 9,891 \\
\hline Total & $111,453,033$ & $38,534,975$ & $15,247,856$ & $13,988,333$ & $11,854,294$ & $20,622,790$ & $5,285,115$ & $4,264,522$ & 905,283 & 749,865 \\
\hline
\end{tabular}

Source: National Statistics Bureau (2009) 
Table 6 reveals that out of total amount of $\$ 31,934,530,920$ allocated in the year 2005, the total sum of $\$ 5,640,000,000$ resulting in 17.7 percent was allocated to tertiary institutions. In the year 2006, $\$ 4,107,000,000$ was allocated to tertiary education out of the total amount of $\$ 63,566,217,470$, and this represents 6.46 percent. This allocation was reduced by $\$ 1,533,000,000$. Similarly, a total sum of $4,934,000,000$ representing 9.64 percent was allocated to tertiary education out of $\$ 51,177,582,116$. There was a slight increase but it was insignificant.

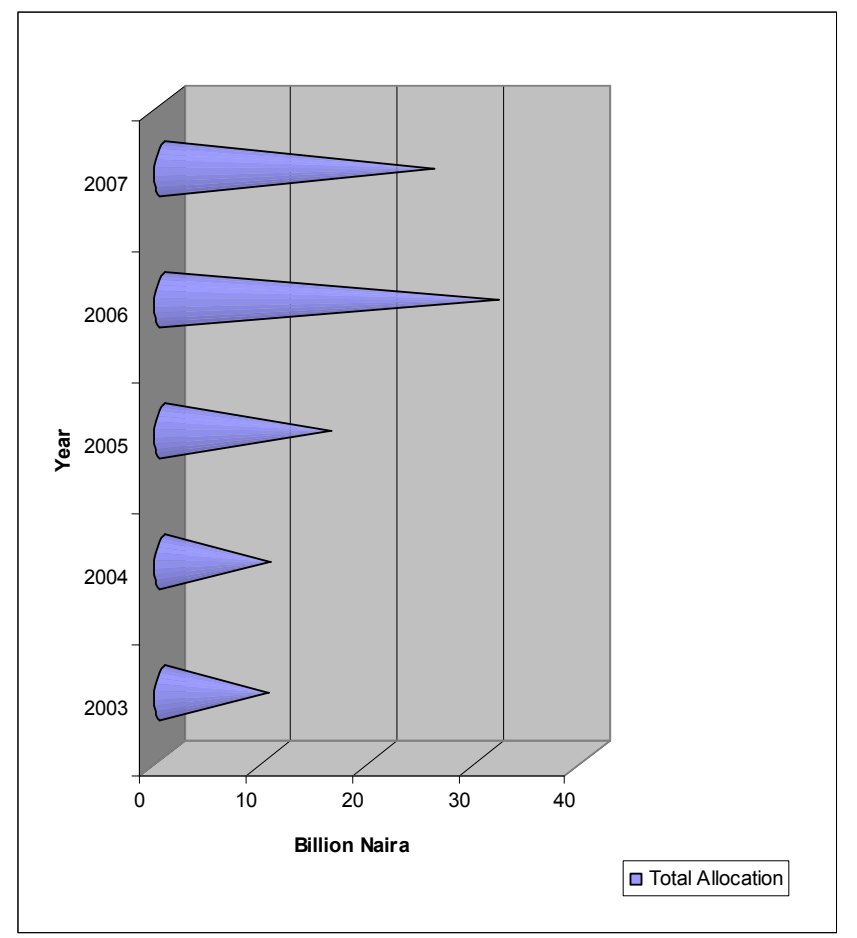

Figure 1. Education Trust Fund Allocations to Institutions, 2003 - 2007

\subsection{Unemployment Rate}

In spite of efforts being made to widen access to higher education in Nigeria, particularly university education, many prospective graduates are still unemployed. Graduate turnout still outpaces graduate employment in Nigeria. This is a serious issue to be addressed by the Nigerian governments.

Table7a. Unemployment Rates by Educational Group, Age Group and Sex (March 2009)

\begin{tabular}{lccc}
\hline ITEMS & Urban & Rural & Composite \\
\hline All Groups & 19.2 & 19.8 & 19.7 \\
Educational Group & & & \\
Never Attended & 20.6 & 20 & 20.1 \\
Below primary & 18.4 & 22.9 & 22.3 \\
Primary & 15.1 & 4.7 & 14.8 \\
Secondary & 21.4 & 25.3 & 23.8 \\
Post secondary & 13.9 & 26.4 & 21.3 \\
\hline
\end{tabular}

Source: National Statistics Bureau (2009) 
Table 7b. Graduate Turn-Out of Bachelor's Degree, Post-Graduate Diploma, Master's Degree and Doctorate Degree Combined, $2001-2005$

\begin{tabular}{|c|c|c|c|c|c|c|c|c|c|c|}
\hline \multirow[t]{2}{*}{ Discipline } & \multicolumn{10}{|c|}{ Year } \\
\hline & Male & Femle & Male & Female & Male & Female & Male & Female & Male & Female \\
\hline Administration & 10,247 & 4,600 & 9,080 & 4,998 & 12,670 & 6,843 & 7,777 & 5,116 & 5,315 & 3,215 \\
\hline Agriculture & 1,558 & 689 & 2,058 & 908 & 1,939 & 1,073 & 1,882 & 987 & 690 & 284 \\
\hline Arts & 3,885 & 2,771 & 4,242 & 3,403 & 4,433 & 4,310 & 3,538 & 3,154 & 2,104 & 1,725 \\
\hline Education & 5,370 & 5,150 & 5,575 & 4,783 & 5,313 & 4,713 & 3,958 & 4,405 & 3,031 & 2,634 \\
\hline Fngineering Technology & 5,215 & 637 & 5,665 & 832 & 6,199 & 1,028 & 4,989 & 819 & 1,824 & 188 \\
\hline ה & 1,343 & 444 & 1,347 & 464 & 1,488 & 699 & 1,335 & 487 & 1,105 & 397 \\
\hline Law & 1,797 & 1,130 & 2,459 & 1,939 & 3,099 & 2,797 & 2,233 & 1,644 & 1,043 & 638 \\
\hline Medicine & 1,316 & 605 & 1,890 & 775 & 1,821 & 1,074 & 1,776 & 868 & 448 & 284 \\
\hline Pharmacy & 269 & 86 & 340 & 154 & 245 & 172 & 433 & 277 & 25 & 17 \\
\hline Science & 6,020 & 3,154 & 5,781 & 3,279 & 6,715 & 4,593 & 5,375 & 2,978 & 5,092 & 1,610 \\
\hline Social Science & 7,633 & 4,056 & 12,708 & 6,201 & 10,693 & 6,662 & 8,853 & 5,269 & 4,170 & 3,113 \\
\hline Dentis ty & 29 & 12 & 46 & 22 & 67 & 30 & 57 & 22 & 2 & - \\
\hline Veterinary Medicine & 98 & 21 & 152 & 53 & 190 & 64 & 86 & 32 & 48 & 13 \\
\hline Others & 832 & 423 & 1,278 & 512 & 1,152 & 497 & 681 & 269 & 280 & 211 \\
\hline Total & 45,612 & 23,778 & 52,621 & 28,323 & 56,024 & 34,555 & 42,973 & 26,327 & 25,177 & 14,329 \\
\hline Grand Total & & 69,390 & & 80,944 & & 90,579 & & 69,300 & & 39,506 \\
\hline
\end{tabular}

Source: National Universities Commission

\section{Assessing the Levels of Tertiary Skills among the Population}

Assessing the level of tertiary skills in the population is another challenge facing the tertiary institutions in Nigeria. Tertiary graduates considered as the stock of highly-educated individuals play an important role in innovation and the sustainable development of a society. However, it takes a relatively long time for a society to build up its stock of highly-skilled individuals. 
Table 8. Population Distribution of Age 6 And Above by Sex, Age Groups and Educational Attainment (Both Sexes) - National, 2006

\begin{tabular}{|c|c|c|c|c|c|c|c|c|c|c|}
\hline \multirow[t]{2}{*}{ Discipline } & \multicolumn{10}{|c|}{ Year } \\
\hline & Male & Femle & Male & Female & Male & Female & Male & Female & Male & Female \\
\hline Administration & 10,247 & 4,600 & 9,080 & 4,998 & 12,670 & 6,843 & 7,777 & 5,116 & 5,315 & 3,215 \\
\hline Agriculture & 1,558 & 689 & 2,058 & 908 & 1,939 & 1,073 & 1,882 & 987 & 690 & 284 \\
\hline Arts & 3,885 & 2771 & 4,242 & 3,403 & 4,433 & 4,310 & 3,538 & 3,154 & 2,104 & 1,725 \\
\hline Education & 5,370 & 5,150 & 5,575 & 4,783 & 5,313 & 4,713 & 3,958 & 4,405 & 3,031 & 2,634 \\
\hline Engine enth lecrimorog & 5,215 & 637 & 5,665 & 832 & 6,199 & 1,028 & 4,989 & 819 & 1,824 & 188 \\
\hline 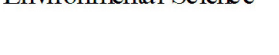 & 1,343 & 444 & 1,347 & 464 & 1,488 & 699 & 1,335 & 487 & 1,105 & 397 \\
\hline Law & 1,797 & 1,130 & 2,459 & 1,939 & 3,099 & 2,797 & 2,233 & 1,644 & 1,043 & 638 \\
\hline Medicine & 1,316 & 605 & 1,890 & 775 & 1,821 & 1,074 & 1,776 & 868 & 448 & 284 \\
\hline Pharmacy & 269 & 86 & 340 & 154 & 245 & 172 & 433 & 277 & 25 & 17 \\
\hline Science & 6,020 & 3,154 & 5,781 & 3,279 & 6,715 & 4,593 & 5,375 & 2,978 & 5,092 & 1,610 \\
\hline Social Science & 7,633 & 4,056 & 12,708 & 6,201 & 10,693 & 6,662 & 8,853 & 5,269 & 4,170 & 3,113 \\
\hline Dentistry & 29 & 12 & 46 & 22 & 67 & 30 & 57 & 22 & 2 & 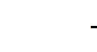 \\
\hline Veterinary Medicine & 98 & 21 & 152 & 53 & 190 & 64 & 86 & 32 & 48 & 13 \\
\hline Others & 832 & 423 & 1,278 & 512 & 1,152 & 497 & 681 & 269 & 280 & 211 \\
\hline Total & 45,612 & 23,778 & 52,621 & 28,323 & 56,024 & 34,555 & 42,973 & 26,327 & 25,177 & 14,329 \\
\hline Grand Total & & 69,390 & & 80,944 & & 90,579 & & 69,300 & & 39,506 \\
\hline
\end{tabular}

Source: National Bureau of Statistics (2009)

As indicated in table 8 , in the year 2006, out of the total population of $111,453,033$, the higher education graduate population was $4,264,522$ which represents $3.83 \%$ of high skilled labor in the country. This is considerably small to make for meaningful development.

\section{Policy Options}

To ensure qualitative higher education in Nigeria, the following policy options could among others be adopted:

1) There should be improved institutional management through strategic planning. This involves adopting total quality management principle towards utilization of allocated resources in an efficient manner. This reduces wastages. This option also embraces revision of higher education curricular to include programs that are more responsive to societal needs.

2) Funding to higher education should be increased and adequate facilities be provided by the government and private organizations. Unless the funding of Federal and state tertiary institutions is properly and frontally addressed, the higher education sector is doomed. All tiers of government from the local council to Federal government should be part of funding process. Private sector should also be allowed to have active and increased participation in funding tertiary institutions in Nigeria.

3) Improving the welfare of teaching and non-teaching staff to ensure their maximum performance should be a priority in our tertiary institutions. 
4) Enrolments in higher education institutions should be on available vacancies.

In addition to the aforementioned options, Okebukola (2010) has identified the following initiatives amongst others, to improve higher education participation rates in Nigeria:

a) Provision of admission spaces in regular universities matching the resources available in such institutions

b) Need to achieve at least 10 percent annual growth in enrolment through a planned and phased expansion with six major components which include: massive upgrading of physical facilities such as classrooms, laboratories, workshops, library and offices in existing universities to take at least additional 1,000 students per year; to add 300,000 more spaces through a gradual increase in the number of universities. Thirty additional universities can be licensed in 10 years by NUC. Fifteen of these should be under private proprietorship and the other fifteen will emerge from upgrades of selected polytechnics.

c) Equivalence granted HND with Bachelor's degree holders and the implementation of the teacher's salary scale are some of the strategies that will make polytechnics and colleges of education attractive to candidates.

\section{Conclusion}

Higher education remains the pivot of national development in Nigeria. Despite the increase in enrolment and Governments' continuous expenditure; the financial and human resources available have not been able to match this demand due to competitions from other sectors of the economy. It is therefore suggested that to ensure qualitative higher education in Nigeria, there should be improved institutional management through strategic planning which consists of the revision of the higher education curricular to include programs that are more responsive to societal needs, increase funding and facilities by government and private organization, improving the welfare of teaching/non teaching staff to ensure their maximum performance on their job, accountability and enrolments into higher education institutions should be on available vacancies.

\section{References}

Adeleye, R. O. (2008). Planning education in Nigeria: Strategies for improvement. Journal of Geography and Regional Planning. 1(7), 122-131. http://www.academicjournals.org/jgrp/PDF/Pdf2008/Oct/Adeleye.pdf

Adu, K., \& Orivel, P. (2006). Financing strategy for tertiary education in Ghana, final report submitted to National Council on Tertiary Education.

Amokaye, G.O. (2004). Environmental law and practice in Nigeria. Lagos: University of Lagos press.

Banya, K. (2001). Sub-Saharan Africa: The state of public higher education and the emergence of private sector university. World Education News and Review, 14(6).

Chevailler, T. (2000). The changing condition of higher education teaching personnel, sectoral activities, programmes. Working paper (IREDU-CNRS/Universite de Bourgogne, ILO Geneva. Retrieved from http://ilo-mirror.library.cornell.edu/public/english/dialogue/sector/papers/education/higheduc.pdf

Federal Republic of Nigeria (2004). National Policy on Education. Federal Republic of Nigeria

Global Education Digest (2009). Comparing Statistics Across the World. UNESCO Institute for Statistics. Retrieved from http://unesdoc.unesco.org/images/0018/001832/183249e.pdf (February 8, 2011)

JAMB (2006). UME Application Statistics. Retrieved from http://www. Jambng.com/ (April 9, 2012)

Johnstone Bruce (2006). Financing higher education: Cost sharing in international perspective. Boston College Center for International Higher Education. Boston. Sense Publishers.

National Bureau of Statistics (2009). Social Statistics in Nigeria. Federal Republic of Nigeria. Retrieved from http://www.nigerianstat.gov.ng/ext/latest_release/ssd09.pdf (December 22, 2011)

National Universities Commission (Dec, 2010). Monday Bulletin, 6(2). Retrieved from http://www.nuc.edu.ng/nucsite/File/Monday\%20Bulletin/MB\%202010/final.pdf (February 8, 2011)

National University Commission (2006). University Enrollment Statistics. National University Commission

Nuhu Y. (2002). Higher education in Nigeria in perspective. In paths to the sustainability of higher education in Nigeria. Social Science Academy of Nigeria, 12-20

Obanya, P. (2004). Education for the knowledge economy. Ibadan: Mosuro Publishers. 
Okebukola, P. (2010). Fifty Years Of Higher Education In Nigeria: Trends In Quality Assurance. A paper presented at the International Conference on the Contributions of Nigerian Universities to the 50th Independence Anniversary of Nigeria. $\quad$ Retrieved from http://unilorin.edu.ng/publiclectures/Final-Okebukola-AVCNU-50-Years\%20of\%20Higher\%20Ed.pdf (April 13, 2011)

Olayemi, A.B. (2000). Town planning: A balancing factor between development and environmental protection. A paper presented at the annual dinner of the Nigerian Institute of Town planners

Sommers P. (2006). "Demand for higher education: A progress report on funding and enrollment of Washington Higher Education". NORED. Retrieved from http://www.washingtonlearns.wa.gov/materials/DemandforHigherEducation_NORED_000.pdf

Task Force on Higher Education and Society (2000). Higher education in developing Countries: Perils and Promise. Washington DC: The World Bank. 135 pages. Retrieved from http://www.accesstosuccess-africa.eu/web/images/literature/peril_and_promise.pdf

The Economist (2005). Survey: Higher education, a world of opportunities. Retrieved from http://www.economist.com (2009)

UNESCO / OECD (2006). World enrollment of tertiary education in World Bank countries. Retrieved from http://www.upo.unesco.org (April 10, 2012)

UNESCO (2003). News Letter. Education Section, 5. Retrieved from http://www.upo.unesco.org (April 10, 2012) 